\title{
Influence of the variability of the odour emission rate on its impact range: a case study of the selected industrial source
}

\author{
Elżbieta Romanik ${ }^{1, *}$, Yaroslav Bezyk ${ }^{1}$, Marcin Pawnuk ${ }^{1}$, Urszula Miller ${ }^{1}$, \\ and Agnieszka Grzelka ${ }^{1}$ \\ ${ }^{1}$ Wroclaw University of Science and Technology, Faculty of Environmental Engineering, \\ Wybrzeże Wyspiańskiego 27, 50-370 Wrocław, Poland
}

\begin{abstract}
Odour concentration measurements in a chosen industrial source were made in this study using the method of dynamic olfactometry. The two different scenarios considered the variation of the odour emission rate as input for the dispersion model were compared for the period 2017 (before installation of the equipment for gas treatment) and 2018 (after implementation of purifying technologies). In this paper the odour impact range was determined by applying model calculations conducted in the Polish reference dispersion model - OPERAT FB software for the grid size $2 \times 2 \mathrm{~km}$. The conducted research shows a significant improvement in the odour impact range of chosen industrial source in year 2018 compared to 2017.
\end{abstract}

\section{Introduction}

The odour nuisance is related to the emission of odours into the atmosphere. The three main groups of emission sources of odours can be distinguished. They include agriculture and animal husbandry, municipal waste management and industry [1]. Analysis of problems and citizens' complaints in Poland, related to the odour impact assessment, identified: $16 \%$ of the complaints lodged against industrial activities, 34\% - about agriculture and breeding, $39 \%$ - as result of municipal management and $11 \%$ related to other sources [2]. Industrial sources of odour nuisance are characterized by the greatest variety. In this group, a wide range of industrial facilities such as agriculture and food processing industry or chemical industry can be distinguished. Due to the large diversity of products and raw materials, such as dry products as plastics, pharmaceuticals, paints, varnishes, rubber products, fertilizers, acids, products, and semi-finished products from crude oil, the odour nuisance associated with the activity of the chemical industry belongs to the most diverse [1].

In general, each of the industrial sources of odours differs both in terms of emitted odorant types and their amount. The amount of odours emission from production operations depends on a number of factors and remedies used to prevent odour nuisance. Industrial facilities are often located in the immediate vicinity of residential areas; therefore, it is necessary to use

* Corresponding author: elzbieta.romanik@pwr.edu.pl 
appropriate techniques to prevent odour emissions into the atmosphere. Among the techniques allowing for the elimination of odorous pollution, the following techniques can be distinguished: combustion, adsorption, absorption, biological methods or deodorization [1]. The use of an appropriate deodorization system allows for effective reduction of the odour emissions of the facility, as well as to improve the quality of life of the local residents.

\section{Methodology}

\subsection{Purpose and methodology of measurements}

The odour emission measurements are carried out in accordance with the methodology described in VDI 3880:2011 [3] and PN-EN 13725:2007 [4] guidelines. Sampling campaigns are mainly performed during rainless weather that will guarantee the efficiency of measurements and repeatability of results. A vacuum sampler (marked CSD30 sampler) and PET-bags, made of chemically inert material, are generally used during samplings. All elements of collecting set are made of odourless materials that do not absorb odorants. According to the recommendations, the bags are previously conditioned. The measurements of weather data including temperature, humidity, and pressure in the sampling day are carried out using a TESTO 435-2 probe system. During the sampling time, the study facilities must be worked without any deflections.

After collection, without delay, the samples of odours are transported to the Olfactory Laboratory. Then, the odour samples are evaluated and quantified to determine odour concentration. Odour concentration measurements are made using the dynamic olfactometry method in accordance with the PN-EN 13725:2007 standards: 'Air quality - determination of odour concentration by dynamic olfactometry' [4]. The odour measuring equipment includes a dilution device - the four-station olfactometer TO8 with the necessary attachments. The obtained data is calculated on the basis of sensitivity tests determined from the geometric mean of all individual measurements. The unit of the odour concentration is reported as the European odour unit per cubic meter $\left(\mathrm{ou}_{\mathrm{E}} / \mathrm{m}^{3}\right)$.

\subsection{Study site}

The industrial facilities investigated in this study are located on the outskirts of a compact urban agglomeration in Poland. In the immediate vicinity, on the northern side of the Plant, an undeveloped area and further the railway line is located. On the eastern side, the Plant is adjacent to another industrial facility. Approximately 1 kilometer to the south of the Plant, there are residential area and services, industrial development and inbuilt areas. There are housing developments at a distance of about $30 \mathrm{~m}$ from the borders on the west side of the Plant. At the distance of the emission impact range up to $850 \mathrm{~m}$ (equal to fifty times of the emitter height) [5] there are no protected objects: national parks, health resorts, monuments/historical treasures or other areas being the subject of the protection in accordance to Polish Nature Conservation Low [6]. Waste gases from plant production activity are discharged to the main emitter that height is $17 \mathrm{~m}$; the release cross-section of the chimney is particularly $2.5 \times 1.2 \mathrm{~m}$. After the system modification (after measurements from 2017), the exhaust air from the production part is centrally purified using a multi-stage adsorb vessel system. 


\subsection{Odour dispersion methods and models}

The mechanisms of dispersion of odorants in the atmosphere are the same as the air based transport of other pollutants. Mathematical models of odour dispersion in the air are used to evaluate the environmental impact of odour-causing substances for various emission release scenarios. The accuracy of the odour dispersion model prediction depends on the multiple input parameters: odour emission data (exit velocity, plume rise, temperature, etc.), sources and surface characteristics (surface roughness, local topography, nearby buildings), meteorological conditions and pollution transformation in the atmosphere (wind speed, stability, mixing height, wind direction) [7]. Based on the dispersion model, it is possible to calculate the odour emission distribution from individual sources as well as area sources. The odour concentrations at receptor points in the study area can be evaluated by using available dispersion models.

Gaussian-type models are the most common dispersion models used in the atmospheric simulation of pollution transport [8]. In general, the most widely used models for simulation of odorous compounds are Gaussian plume (e.g. AERMOD) and Gaussian puffs (e.g. CALPUFF) distribution software. Each one has its own advantages and disadvantages associated with the steady-state approximations and the vertical particle movement due to gravity during the travel time [9]. The Operat FB model developed based on Gaussian plume, is mainly used in Poland for predicting odour concentration and calculating odour emission rates [5]. The model is based on knowledge and the assumption of the atmospheric transport of pollution, especially relating to the constant and uniform emission rates; constant parameters of the wind and speed direction; processes of vertical and crosswind diffusion; and the terrain domain.

\section{Results and discussion}

\subsection{Emission calculations}

The odour emission from the installation was calculated as mean odour concentration and exhaust gas flow rate on the main/cetral emitter (CE). The gas flow was specified for the standard conditions as required by PN 13725:2007 [4].

where:

$$
E=\frac{C \cdot V}{3600} \quad\left[o u_{E} / s\right]
$$

$\mathrm{E}$ - odour emission from emitter, $\left[\mathrm{ou}_{\mathrm{E}} / \mathrm{s}\right]$;

$\mathrm{C}$ - odour concentration at the outlet, $\left[\mathrm{ou}_{\mathrm{E}} / \mathrm{m}^{3}\right]$;

$\mathrm{V}$ - gas flow rate in the emitter, $\left[\mathrm{m}^{3} / \mathrm{s}\right]$.

On the basis of the olfactometric measurements, the average odour concentrations (expressed in ou $/ \mathrm{m}^{3}$ units) in collected gas samples were determined. The comparison of the obtained results for the years 2017-2018 is represented in Table 1.

The results of odour concentration measurements from 2018 show the high decreasing in odour level by $11896 \mathrm{ou}_{\mathrm{E}} / \mathrm{m}^{3}$ as compared with the samplings applied in 2017 . The reduction of the odour concentration at the outlet of the emitter is caused by the introduction of modifications in the deodorization installation of waste gases from the Plant. 
Table 1. Comparison of the odour concentrations measured in 2017 and 2018.

\begin{tabular}{|c|c|c|c|c|}
\hline $\begin{array}{c}\text { Emitter } \\
\text { name }\end{array}$ & Date & $\begin{array}{l}\text { Sample } \\
\text { name }\end{array}$ & $\begin{array}{c}\text { Odour concentration, } \\
{\left[0 u_{E} / \mathbf{m}^{3}\right]} \\
\end{array}$ & $\begin{array}{c}\text { Average concentration, } \\
{\left[0 u_{E} / \mathbf{m}^{3}\right]}\end{array}$ \\
\hline \multirow{6}{*}{$\begin{array}{c}\text { Central } \\
\text { emitter (CE) }\end{array}$} & \multirow{3}{*}{2017} & $\mathrm{CE} / 6$ & 12784 & \multirow{3}{*}{12127} \\
\hline & & $\mathrm{CE} / 8$ & 11324 & \\
\hline & & $\mathrm{CE} / 11$ & 12274 & \\
\hline & \multirow{3}{*}{2018} & $\mathrm{CE} / 1$ & 196 & \multirow{3}{*}{231} \\
\hline & & $\mathrm{CE} / 2$ & 299 & \\
\hline & & $\mathrm{CE} / 3$ & 196 & \\
\hline
\end{tabular}

\subsection{Input model data}

Calculations of the odour dispersion in the Plant surrounding areas were carried out in the reference of the Regulation of the Minister of Environment dated 26 January 2010 on reference values for some substances in the air (Journal of Laws 2010, no. 16, item 87) [5]. Modelling criteria used in the study included the basic values of emission source parameters (emitter height and diameter, odour emission rate), as well as the current dispersion conditions (meteorological data and topographical features).

Modelling of odours dispersion was performed based on the following scenarios:

- the analysis performed in normal mode at the maximum system capacity before installing the gas deodorization system (on the year 2017).

- the analysis performed in normal mode at the maximum system capacity after installing the gas deodorization system (on the year 2018).

The comparison of the parameters of emitters, results of odour emission calculations and meteorological data obtained for 2017 and 2018 is represented in Table 2. The odours emissions from the central emitter (CE) were $68620.74 \mathrm{ou}_{\mathrm{E}} / \mathrm{s}$ and $4899.56 \mathrm{ouE} / \mathrm{s}$ in 2017 and 2018 , respectively. The average odour concentration in 2017 was $12127.33 \mathrm{ou}_{\mathrm{E}} / \mathrm{m}^{3}$, while in 2018 did not exceed $230.33 \mathrm{ou}_{\mathrm{E}} / \mathrm{m}^{3}$.

Table 2. Comparison of emitter parameters and results of odour emission calculations in 2017 and 2018.

\begin{tabular}{|c|c|c|c|c|c|c|c|c|c|}
\hline 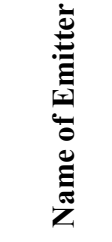 & 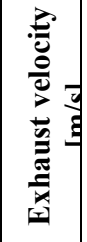 & 离 & 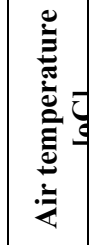 & 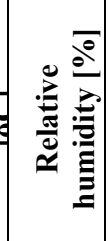 & 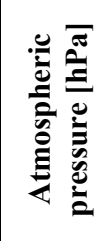 & 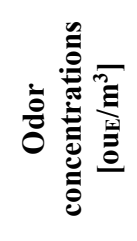 & 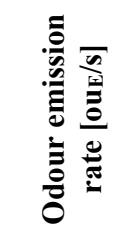 & 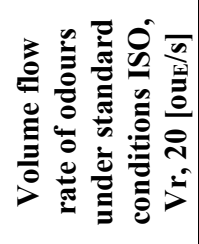 & 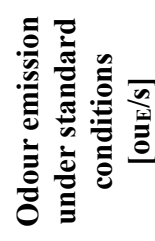 \\
\hline $\begin{array}{c}\mathrm{CE} \\
(2017)\end{array}$ & 3.01 & 5.89 & 24.27 & 100.00 & 987.21 & 12127.33 & 71439.48 & 5.66 & 68620.74 \\
\hline $\begin{array}{c}\mathrm{CE} \\
(2018)\end{array}$ & 7.12 & 21.35 & 21.21 & 76.32 & 1013.31 & 230.33 & 4917.62 & 21.27 & 4899.56 \\
\hline
\end{tabular}

Calculations of the odour impact range were carried out in grid format receptors with selected size and step of each grid cells and coefficient of aerodynamic roughness. The grid size was determined to be equal to $2000 \mathrm{~m}$ x $2100 \mathrm{~m}$ with a grid step at $50 \mathrm{~m}$. The coefficient of aerodynamic roughness identified in the area within 50 times radius of the emitter height [5] was $0.353 \mathrm{~m}$. 


\subsection{Results of the odour dispersion modelling}

The OPERAT FB - a Polish reference dispersion model (according to Regulation of the Minister of the Environment of 26 January 2010 on reference values for certain substances in the air [5]) was applied in the analysis of the odour impact range. The environmental detection threshold for odours as a mixture for residential areas under the Polish conditions [10] is established within the range of values $1 \mathrm{ou}_{E} / \mathrm{m}^{3}$. The maximum frequency of exceedances of the odour concentration at a level of $1 \mathrm{ou}_{\mathrm{e}} / \mathrm{m}^{3}$ is determined at $3 \%$ during the year [10]. The results of the obtained maximum odour concentration in the receptor grid are shown in Table 3 . The maximum annual odour concentration in the testing area were 1.3863 and $0.0296 \mathrm{ou}_{\mathrm{E}} / \mathrm{m}^{3}$ for the year 2017 and 2018 , respectively. The maximum frequency of the exceedance of the odour concentration of $1 \mathrm{ou}_{\mathrm{E}} / \mathrm{m}^{3}$ was $19.45 \%$ in 2017 . In the year 2018 there were no exceedances of odour detection threshold in the calculation grid for industrial Plant.

Table 3. Comparison of the maximum odour concentration in the receptor network in 2017 and 2018.

\begin{tabular}{|c|c|c|c|c|c|c|c|}
\hline \multirow{2}{*}{$\begin{array}{l}\text { Name of } \\
\text { pollutant }\end{array}$} & \multicolumn{3}{|c|}{$\begin{array}{c}\text { Frequency of exceedances of } \\
1 \mathrm{ouE} / \mathrm{m}^{3} \text { per year }[\%]\end{array}$} & \multicolumn{4}{|c|}{$\begin{array}{l}\text { Maximum annual concentrations in the } \\
\text { receptor network }\left[\mathrm{ouE}_{\mathrm{E}} / \mathrm{m}^{3}\right]\end{array}$} \\
\hline & \multicolumn{2}{|c|}{ Calculated } & \multirow[t]{2}{*}{ Limit } & \multicolumn{2}{|c|}{ Calculated } & \multicolumn{2}{|c|}{ Limit } \\
\hline \multirow{2}{*}{ Odours } & 2017 & 2018 & & 2017 & 2018 & 2017 & 2018 \\
\hline & 19.45 & 0.00 & $<3$ & 1.3863 & 0.0296 & $>1$ & $<1$ \\
\hline
\end{tabular}

The results of the modelling of maximum odour concentration values outside the Plant border at additional points marked as residential buildings are compared in Table 4 . The highest annual odour concentration occurred at the point B4; the provided value was up to $37.821 \mathrm{ou}_{\mathrm{E}} / \mathrm{m}^{3}$ for 2017 and $0.358 \mathrm{ou}_{\mathrm{E}} / \mathrm{m}^{3}$ for the year 2018 .

Table 4. Comparison of odour concentrations calculated for additional points in the receptor network in 2017 and 2018.

\begin{tabular}{|c|c|c|c|c|c|c|c|}
\hline \multirow[b]{2}{*}{ No. } & \multirow[b]{2}{*}{$\begin{array}{c}\text { Name o } \\
\text { point }\end{array}$} & \multicolumn{3}{|c|}{2017} & \multicolumn{3}{|c|}{2018} \\
\hline & & $\begin{array}{c}\text { Max. conc. } \\
\text { ou } / \mathbf{m}^{3}\end{array}$ & $\begin{array}{c}\text { Avg. conc } \\
\text { ou } / \mathbf{m}^{3}\end{array}$ & $\begin{array}{c}\text { Freq. of exceed., } \\
1 \mathrm{ou} / \mathrm{m}^{3}[\%]\end{array}$ & $\begin{array}{l}\text { Max. conc. } \\
\text { ou } / \mathbf{m}^{3}\end{array}$ & $\begin{array}{c}\text { Avg. conc. } \\
\text { ou } / \mathbf{m}^{3}\end{array}$ & $\begin{array}{c}\text { Freq. of } \\
\text { exceed., } 1 \mathrm{ou} / \mathbf{m}^{3} \\
{[\%]}\end{array}$ \\
\hline 1 & B1 & 31.852 & 0.2371 & 5.61 & 0.303 & 0.0061 & 0.00 \\
\hline 2 & B2 & 27.050 & 0.1230 & 2.84 & 0.282 & 0.0033 & 0.00 \\
\hline 3 & B3 & 28.747 & 0.1198 & 2.74 & 0.287 & 0.0032 & 0.00 \\
\hline 4 & B4 & 37.821 & 0.2917 & 5.84 & 0.358 & 0.0068 & 0.00 \\
\hline 5 & B5 & 25.132 & 0.3229 & 6.34 & 0.282 & 0.0075 & 0.00 \\
\hline 6 & B6 & 21.257 & 0.1883 & 3.87 & 0.275 & 0.0048 & 0.00 \\
\hline 7 & B7 & 15.390 & 0.0997 & 1.83 & 0.233 & 0.0028 & 0.00 \\
\hline 8 & B8 & 21.035 & 0.1688 & 3.43 & 0.274 & 0.0048 & 0.00 \\
\hline
\end{tabular}

The frequency of the exceeding of a given one-hour odour concentration threshold in the year 2017 and 2018 is shown in figure 1 . Comparing the left and the right panel in fig. 1, the large differences in the impact distances of odour emission before and after modification purifying system can be seen. The exceedance level of $1 \mathrm{ou}_{\mathrm{E}} / \mathrm{m}^{3}$ and $3 \%$ is much more pronounced at calculation grid for 2017, in distance towards the north exceeds $400 \mathrm{~m}$ and approximately $500 \mathrm{~m}$ to the east of the Plant boundaries. In 2018, the frequency of exceedances of one-hour odour concentration has not occurred. Modelling of odour 
dispersion based on measurements of their emissions in 2018 shows the significant improvements in the frequency of exceeding compared to 2017 (when it was 19.45\%).
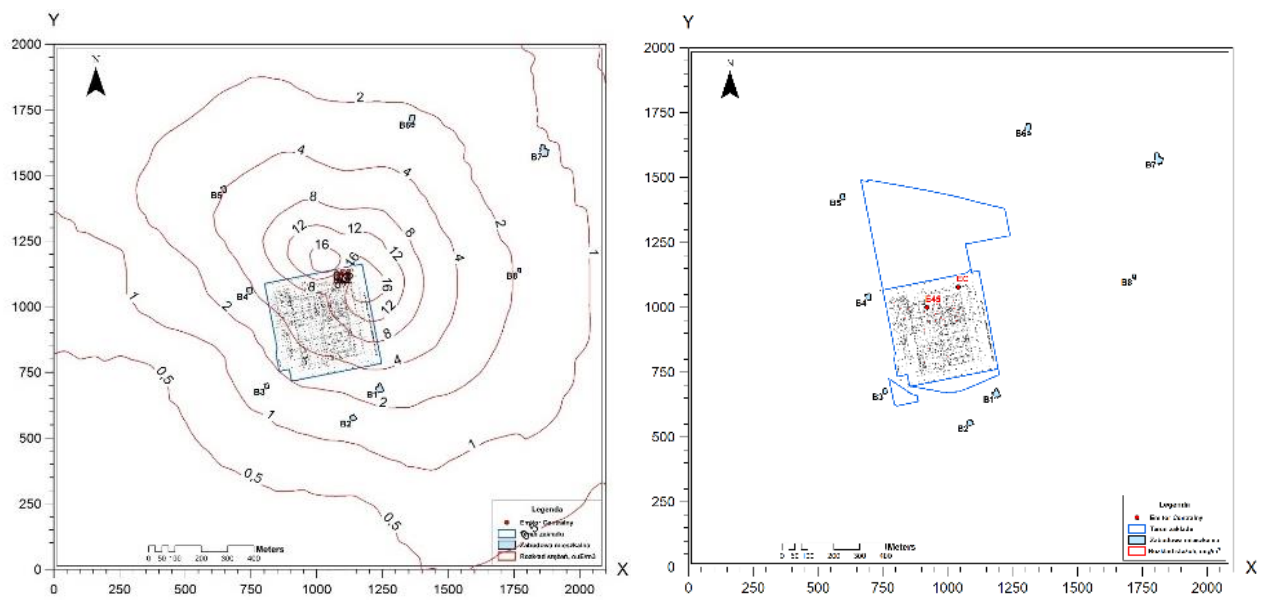

Fig. 1. The frequency of exceeding of the one-hour odour concentrations (exceedance threshold of $3 \%$ ) in 2017 (left side) vs 2018 (right side).

The distribution of average odour concentrations in 2017 compared to 2018 is shown as isolines at the study grid in figure 2 . The exceedance of the given odour threshold of $1 \mathrm{ou} / \mathrm{m}^{3}$ is determined at the distance of approximately $50 \mathrm{~m}$ towards the east from the Plant boundaries and $80 \mathrm{~m}$ towards the north.
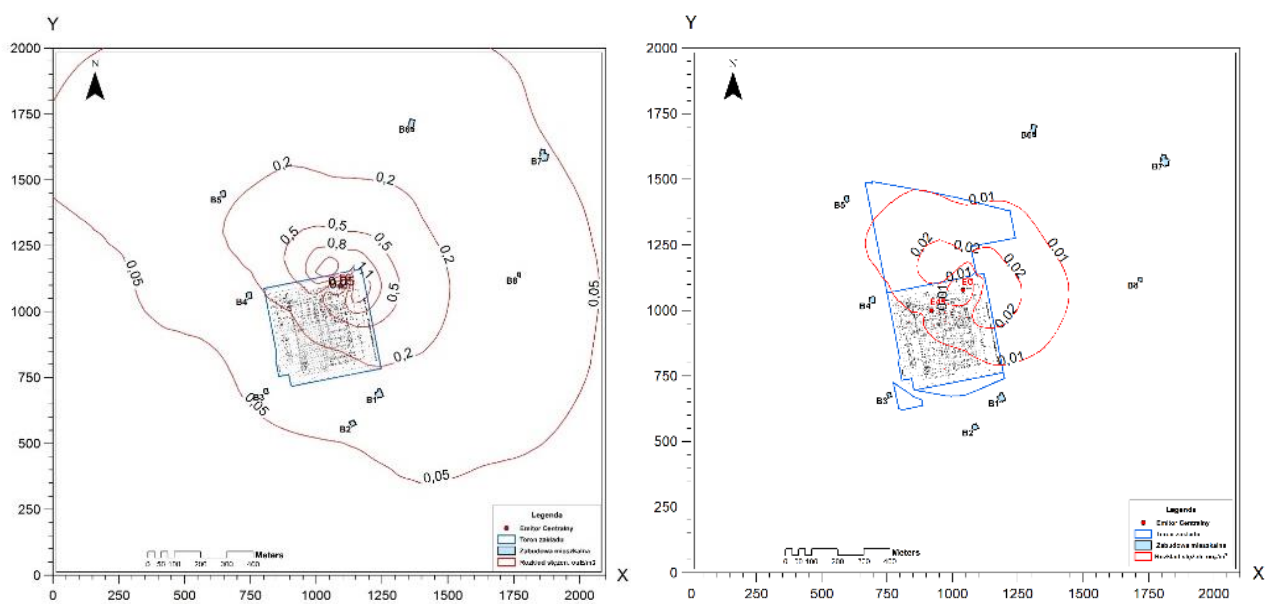

Fig. 2. The average odour concentrations, ou $/ \mathrm{m}^{3}$ (exceedance threshold of $1 \mathrm{ou}_{\mathrm{E}} / \mathrm{m}^{3}$ ) in 2017 (left side) vs 2018 (right side).

In figure 3, the distribution of maximum odour concentrations in 2017 is compared to 2018. Exceedances of $1 \mathrm{ou}_{\mathrm{E}} / \mathrm{m}^{3}$ limit have occurred in all directions of the calculation grid (over $1000 \mathrm{~m}$ of plant boundaries). The distribution of maximum odour concentration in 2018, has not exceeded the limit of $1 \mathrm{ou}_{\mathrm{E}} / \mathrm{m}^{3}$ at any point of the calculation grid. Maximum of annual average odour concentration calculated on the basis of measurements from 2018 amounted to $0.0296 \mathrm{ou}_{\mathrm{E}} / \mathrm{m}^{3}$ and emissions determined in 2017 was equal to $1.3863 \mathrm{ou}_{\mathrm{E}} / \mathrm{m}^{3}$. In addition, the distincly different odour impact range in a study period 2017-2018 is caused 
by a significant difference in the values of odour emmisions from the central emitter. The comparison of the odour impact range obtained for the year 2018 shows a significant reduction in the intensity of emission from the central emitter, in relation to the values in 2017.
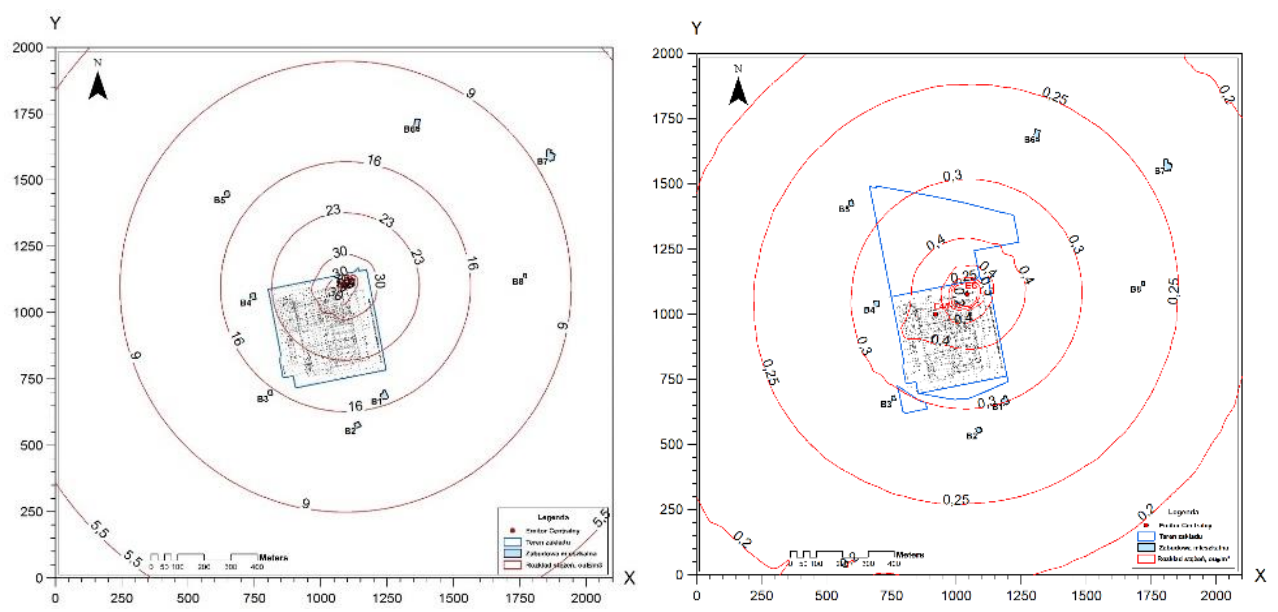

Fig. 3. The maximum odour concentrations, ouE $/ \mathrm{m}^{3}$ (exceedance threshold of $1 \mathrm{ouE} / \mathrm{m}^{3}$ ) in 2017 (left side) vs 2018 (right side).

In case of the odour dispersion modelling the predicted concentrations in the environment were used for designating areas and populations affected by the odour nuisance. At the selected points within the study grid, where the residential buildings were located, the significant improvement in the air quality was observed in 2018 compared to 2017. The highest value of average annual maximum concentrations of odours was determined in the point $\mathrm{B} 4$, at the level of $37.821 \mathrm{ou}_{\mathrm{E}} / \mathrm{m}^{3}$ and $0.358 \mathrm{ou}_{\mathrm{E}} / \mathrm{m}^{3}$ in 2017 and 2018 , respectively. According to the average concentrations of odours, the highest value was evaluated in the point B5. The average odour levels were found to be $0.3229 \mathrm{ou}_{\mathrm{E}} / \mathrm{m}^{3}$ in 2017 , while in $2018-0.0075 \mathrm{ou}_{\mathrm{E}} / \mathrm{m}^{3}$. According to the emission ranges, results show that the development of solutions for the improvement of the existing production and deodorization conditions may prove helpful in limiting the odour dispersion.

\section{Summary and conclusions}

Most complaints related to chemical odours are associated with industrial facilities that should continue to improve its odour control performance. The emission of odours into the atmosphere from the industrial plants, especially in urban areas, can cause problems related to odour nuisance, and thus even negative health effects. In order to asses the odour impact before and after an industrial plant upgrade, the odour concentration measurements by dynamic olfactometry method was used in this study. The prediction of odour concentrations determined by the Polish reference dispersion model pointed to the direct impact of the modernization of production lines and the deodorization system in the analysed Plant. The model calculations of the odour impact range with respect to the emission values show that the distance of odour dispersion decreases with the emission decrease. The research results indicate that odour evaluation and dispersion modelling are valid tools in the evaluation of odour control improvements implemented by the operators of industrial facilities. 
The study was co-financed within the framework of the project No. 0402/0095/18 with the specific subsidy granted for the Faculty of Environmental Engineering Wroclaw University of Science and Technology (W7) by the Minister of Science and Higher Education to conduct research and development work and related tasks contributing to the development of young scientists and doctoral students in 2018/2019.

\section{References}

1. M. Szklarczyk, J. Zwoździak, I. Sówka, Industrial sources of odour emissions, In: M. I. Szynkowska, J. Zwoździak (Eds.), Współczesna problematyka odorów (Wyd. Naukowo-Techniczne, Warszawa, 2010)

2. I. Sówka Methods of identyfication of odour gases emitted from industrial pants (Oficyna Wydawnicza Politechniki Wrocławskiej, Wrocław, 2011)

3. VDI 3883: Olfactometry. Static sampling (Verein Deutscher Ingenieure, 2011)

4. PN-EN 13725:2007: Air quality. Determination of odour concentration, with the use of dynamic olfactometry method

5. Regulation of the Minister of Environment dated 26 January 2010 on reference values for some substances in the air. (Journal of Laws 2010, no. 16, item 87).

6. The Act of Nature Convesration, of 16 April 2004 (Journal of Laws 2004 no. 92, item 880)

7. I. Sówka, Y. Bezyk, A. Grzelka, U. Miller, Ł. Pachurka, Wat. Sci. \& Tech. 2017, 2 (2017)

8. N. S. Holmes, L. Morawska, Atm. Env. 40, 30 (2006)

9. A. S Rood, Atm. Env. 89 (2014)

10. Draft law on preventing odour nuisance from 27.02.2009 (Poland) 